\title{
Inventory of Land Snail in Darungan Lake, Bromo Tengger Semeru National Park 2019
}

\author{
Putri Afin Nurhayati $^{1}$, Boni Herdiawan ${ }^{2}$, Galuh Ayu Chantika Dwitara ${ }^{1}$ \\ ${ }^{1}$ Biology Department, Science and Technology Faculty, Airlangga University \\ ${ }^{2}$ Generasi Biologi Indonesia Zoology Division, Gresik 61171, East Java, Indonesia \\ *email: putri.afin.nurhayati-2017@fst.unair.ac.id
}

\begin{tabular}{|c|c|}
\hline Article Info & ABSTRACT \\
\hline Key word: & This study aims to determine the diversity of land snails that \\
\hline Biodiversity & have never been revealed before. The location of this research \\
\hline Land snail & is in the forest in the Ranu Darungan Resort area of Bromo \\
\hline Darungan Lake & Tengger Semeru National Park. The method used in this study \\
\hline Bromo & $\begin{array}{l}\text { is the } 1.5 \mathrm{~km} \text { transect line method. Land snails are often found } \\
\text { behind leaves, around tree roots, and around leaf litter. The }\end{array}$ \\
\hline Article history: & results of this study obtained 20 species of land snails, each of \\
\hline Received: 02/02/2020 & which has different characteristics. Land snail identification is \\
\hline Revised: $28 / 03 / 2020$ & using a land snail identification book. The lack of information \\
\hline Accepted: $17 / 04 / 2020$ & $\begin{array}{l}\text { about land snalls in the Ranu Darungan Resort area makes this } \\
\text { research expected to be the basis for further research. }\end{array}$ \\
\hline
\end{tabular}

Copyright $(2020$ Universitas Islam Negeri Raden Fatah Palembang. All Right Reserved

\section{Introduction}

Bromo Tengger Semeru National Park (BTSNT) is one of several national parks in East Java Province that has a diversity of ecosystems and a diversity of flora and fauna. Bromo Tengger Semeru National Park (BTSNT) was appointed through the statement of the minister of agriculture no.736 / Mentan / X / 82 dated October 14, 1982. The technical implementation of BTSNT is under the responsibility of the Director General of forest protection and nature conservation. Bromo Tengger National Park has 2 ecosystems which include terrestrial and aquatic ecosystems. Ranu Darungan is one of the aquatic ecosystems owned by BTSNT. Ranu Darungan has an area of about 2 hectares, located at an altitude of 750 meters above sea level. Ranu Darungan is a reservoir of cold lava flow until finally the water is flowed by the forest around the lake. Forest and aquatic ecosystems in Ranu Darungan turned out to have quite diverse diversity. This diversity is one of them is land snails that can be found around Ranu Darungan. Land snail (land snail) is a group of mollusks that are familiar with several characteristics such as having paired eyes located at the tip of the tentacles, a pair of sensory tentacles, a circular shell as a protector and underneath the head there is a mouth equipped with a radula. Land snails usually live in the ground, bush or tree by eating decomposed organic matter and storing eggs in moist soil. This research is about the diversity of land snails found in leaves in the forest around Ranu Darungan to provide information and data collection on land snail diversity.

\section{Materials and Methods}

This research was carried out on April 19, 2019 in Bromo Tengger Semeru National Park, at the foot of Mount Semeru Resort Ranu Darungan. by exploration along 
1.5 kilometers. Exploration of land snails is sought behind fresh leaves, leaf litter that has fallen, and behind rocks and weathered wood.

\section{Results and Discussion}

Based on sampling, 12 different species were found as mentioned in Table 1. Species List. The environmental conditions carried out by the exploration were slightly wet due to the influence of the rain that occurred the night before. Land snail species are found living behind fresh leaves such as Liardetia indifferens, this species is also found in Sumatra, Gunung Ceremai National Park, Lampung, Sawal Mountain and Boyolali District (Maassen, 2000; Heryanto, 2008; Heryanto, 2013 ; Heryanto, 2017; Gamellia, 2017), Liardetia acutiuscula, this species is also found in Sumatra and Boyolali District. (Marwoto, 2016; Gamellia, 2017), and Gheophorus oxytropis which have not been recorded for the presence of species in Indonesia. Besides being found behind fresh leaves, land snails are also found on the surface of the leaves and stem stems such as Helicarion albellus and Helicarion perfragilis which can be found in the Mount Ciremai National Park, Karst Sukolilo, Boyolali, Gunung Sawal, Sumatra and Bogor. (Heryanto 2008; Nurinsiyah, 2015; Gamellia, 2017; Heryanto, 2017; Marwoto, 2016; Wijaya, 2019), Ganesella bantamensis whose existence was recorded in the Lampung area (Mujiono, 2019), and Amphidromus furcillatus which can also be found in Malang, Java East and Purworejo, Central Java (Nurinsiyah, 2016; Mujiono, 2017). There are also land snails found in leaf or wood litter such as Cyclophorus perdix perdix which can also be found in the Ciremai Mountain National Park, the Karol Sukolilo area, Sumatra, Bogor. (Heryanto, 2008; Nurinsiyah, 2015; Marwoto, 2016; Wijaya, 2019) and Hemiplecta humphreysiana can be found in Banjarbaru, South Kalimantan and Bogor, West Java. (Muhamat, 2009; Wijaya, 2019). The diversity of land snails in the Ranu
Darungan Resort, provides an indicator that environmental conditions still provide the environmental carrying capacity to be inhabited by species not only found in the Ranu Darungan Resort area. The need to preserve habitat so that the diversity of organisms in it is also still sustainable
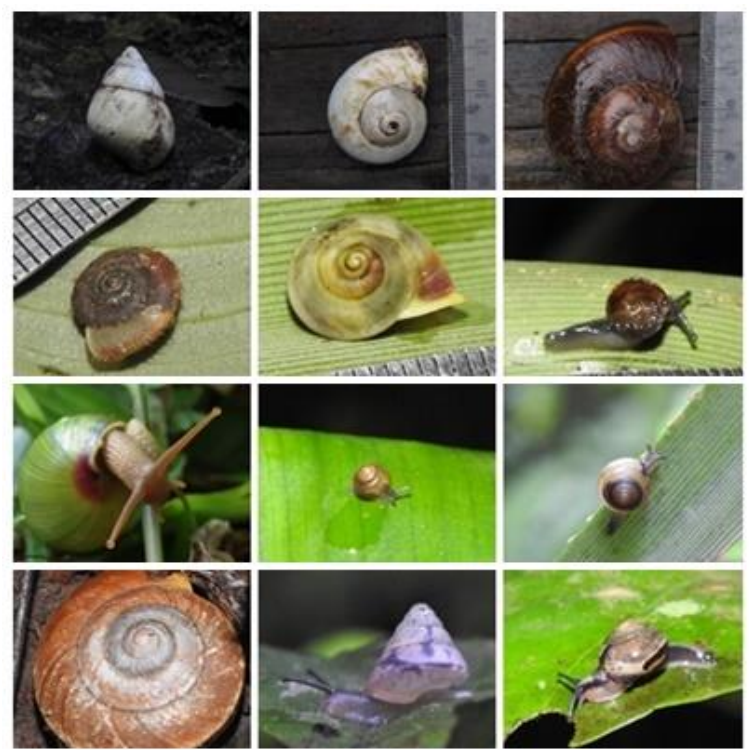

Figure 1. Diversity of land snails at Ranu Darungan Resort, BTSNT

\section{Tabel 1. Species List}

\begin{tabular}{cc}
\hline Family & Species \\
\hline Helicarionidae & Liardetia indifferens \\
Helicarionidae & Helicarion perfragilis \\
Helicarionidae & Helicarion albellus \\
Helicarionidae & Liardetia acutiuscula \\
Camaenidae & Ganesella bantamensis \\
Camaenidae & Landouria madurensis \\
Camaenidae & Amphidromus furcillatus \\
Ariophantidae & Hemiplecta humphreysiana \\
Helicinidae & Gheophorus oxytropis \\
Pyramidulidae & Pyramidula javana \\
Dyakiidae & Elaphroconchapatens \\
Cyclophoridae & Cyclophorus perdix perdix \\
\hline
\end{tabular}

\section{Acknowledgment}

This paper would not be meaningful without the assistance of Mr. Heryanto as LIPI researcher, Mr. Toni Arkasa, head of the Ranu Darungan Resort, and Ms. Reni Ambarwati, a biology lecturer at Surabaya State University. The author also thanks the parties who helped in providing information and motivation. 


\section{References}

Marwoto , R.M. (2016). Keong Darat Dari Sumatera (Moluska, Gastropoda) The Occurence of The Terrestrial Snail From Sumatra (Mollusca, Gastropod). Zoo Indonesia, 25(1), 8-21.

Heryanto. (2013). Keanekaragaman dan Kepadatan Gastropoda Terestrial di Perkebunan Bogorejo, Kecamatan Gedongtataan, Kabupaten Pesawaran, Provinsi Lampung. Zoo Indonesia, 22(1), 23-29

Garmellia, L. N., Hidayat, J. W., \& Muhammad, F. (2017). KEANEKARAGAMAN MOLUSKA TERESTRIAL DI JALUR PENDAKIAN SELO TAMAN NASIONAL GUNUNG MERBABU, KABUPATEN BOYOLALI, JAWA TENGAH. Jurnal Akademika Biologi, 6(3), 50-56.

Heryanto. (2017). Keragaman Keong Darat Di Hutan Suksesi di Gunung Galunggung dan Hutan Tua di Gunung Sawal, Jawa Barat. Zoo Indonesia, 2017 26(2), 59-69.

Maassen , W.J.M. (2000). Notes on terrestrial molluscs of Sumatra, Indonesia, with descriptions of ten new species (Gastropoda, Prosobranchia \& Pulmonata). Basteria, 64, 137-150.

Heryanto. (2008). Ekologi Keong Darat di Taman Nasional Gunung Ciremai. Jurnal Biologi Indonesia, 4(5), 359370.

Nurinsiyah A. S. (2015) . Land Snail Fauna of the Sukolilo karst in Java (Indonesia. American Conchologist, 43(3), 30-32.

Mujiono, N., dkk. (2019). Keanekaragaman dan Distribusi Dua Suku Keong Darat Sumatra (Gastropoda: Camaenidae dan Cychloporidae). Berita Biologi, 18(3), 325-338.

Mujiono, N. (2017). Desa Kaligono, Rumah Bagi Keong Pohon Amphidromus (Gastropoda : Camaenidae). Zoo Indonesia, 26(2), 130-136.

Wijaya, W.A., dkk. (2019). Keanekaragaman Jenis Keong Darat di
Taman Wisata Alam Telaga Warna, Bogor, Jawa Barat. Bioeduscience, 3(1), 14-22.

Nurinsiyah A.S. Et Al. (2019). Revision of the Land Snail Genus Landouria Godwin-Austen, 1918 (Gastropoda, Camaenidae) from Java. European Journal of Taxonomy, 526, 1-73.

Muhamat. (2009). Diversitas Bekicot di Kota Banjarbaru Kalimatan Selatan. Bioscientiae, 6(2), 49 - 53.

Nurinsiyah A.S. Et Al. (2016). Native and Introduced Land Snail Species as Ecological Indicators in Different Land Use Types in Java. Ecological Indicators, 70, 557-565. 